Rowlands (consultant cardiologists) for allowing us to study their patients; Dr R S H Pumphrey and Miss D Burrows of the department of immunology, St Mary's Hospital, Manchester, for performing immunological tests; and Mrs D Ward for typing the manuscript. The work was supported by a grant from the Arthritis and Rheumatism Council.

1 Edeiken J, Wolferth CC. Persistent pain in the shoulder region following myocardial infarction. Am 7 Med Sci 1936;191:201-10.

2 lirnstene AC Kinell J. Pain in the shoulders as a sunel to myocardia infarcion

3 Askev JM. The sundrome of painful disability of the shoulder and hand complicating coronary occlusion. Am Heart f 1941;22:1-12.

4 Edeiken J. Shoulder-hand syndrome following myocardial infarction with deiken J. Shoulder-hand syndrome following myocardia
special reference to prognosis. Circulation 1957;16:14-9.

5 Soloff LA, Zatuchni J, Janton H, O'Neill TJ, Glover RP. Reactivation of rheumatic fever following mitral commissurotomy. Circulation 1953;8 $481-4$.

6 Elster SK, Wood HF, Seely RD. Clinical and laboratory manifestations of the postcommissurotomy svndrome. Am 7 Med 1954;17:826-38.

7 Dresdale DT, Ripstein CB, Guzman SV, Greene MA. Postcardiotomy syndrome in patients with rheumatic heart disease. $A m \mathcal{F}$ Med 1956;21: $57-74$.

8 Engle MA, Ito T. The postpericardiotomy syndrome. Am $\mathcal{f}$ Cardiol 1961;7: $73-82$

9 Larson DL. Relation of the postcommissurotomy syndrome to the rheumatic state. Circulation 1957;15:203-9.

10 Epstein S. Is the postcommissurotomy svndrome of rheumatic origin? Arch Intern Med 1957:99:253-9.

11 Ito T, Engle MA, Goldherg HP. Postpericardiotomy syndrome following surgery for nonrheumatic heart disease. Circulation 1958;17:549-56.

12 Stelzner TJ, King TE Jr, Antony VB, Sahn SA. The pleuropulmonary manifestations of the post-cardiac injury syndrome. Chest 1984;84:383-7

13 Dressler $W$. The postmyocardial infarction syndrome: a report on 44 cases. Arch Intern Med 1959;103:28-42.

If Davidson C. Arthropathy in Dressler's syndrome. Postgrad Med f 1981;57 $60-1$.

15 Kreel I, Zaroff LI, Canter JW, Krasna I, Baronofsky ID. A syndrome following total bodv perfusion. Surg Gynecol (Obstet 1960;111:317-21.

6 Seaman AJ, Starr A. Febrile postcardiotomy lymphocytic splenomegaly: a new entity. Ann Surg 1962:156:956-60.

17 Wheeler EO, Turner JD, Scannell JG. Fever, splenomegaly and atypical lymphocytes: syndrome observed after cardiac surgery utilizing a pump oxygenator. N Engl f Med 1962;266:454-6.

18 Smith DR. A syndrome resembling infectious mononucleosis after open heart surgery. Br Med f 1964;i:945-8.

19 Papp C, Zion MM. The postcommissurotomy syndrome. Br Heart $\mathcal{J}$ 956;18: 153-65.

20 Drusin LM, Engle MA, Hagstrom JWC, Schwartz MS. The postpericardiotomy syndrome: a six-year epidemiologic study. $N$ Engl 7 Med 1965;272:597-602

21 McCabe JC, Ebert PA, Engle MA, Zabriskie JB. Circulating heart-reactive antibodies in the postpericardiotomy syndrome. 7 Surg Res 1973;14:158.

22 Engle MA, McCabe JC, Ebert PA, Zabriskie JB. The postpericardiotomy syndrome and antiheart antibodies. Circulation 1974;49:401-6.

23 Engle MA, Zabriskie JB, Senterfit LB, Tay DJ, Ebert PA. Immunologic and virologic studies in the postpericardiotomy syndrome. $\mathcal{F}$ Pediatr 1975;87: 1103-8.

24 Engle MA, Zabriskie JB, Senterfit LB, et al. Viral illness and the postpericardiotomy syndrome: a prospective study in children. Circulation 1980;62:1151-8.

25 Engle MA, Gay WA, MCCabe J, et al. Postpericardiotomy syndrome in adults: incidence, autoimmunity and virology. Circulation 1981;64(suppl 2):58-60. incidence, autommunity and virology. Circulation 1981;64(suppl 2):58-60.
Strausz I, Dobias GY. Autoantibodies reacting with heart muscle tissue in coronary heart disease. $\mathcal{F}$ Clin Pathol 1967;20:161-5.
coln

27 Kuch J, Chorzelski T. Immunofluorescence studies in recent myocardial infarction. Cardiorvascular Res 1971;5:353-7.

28 Bauer $\mathrm{H}$, Waters TJ, Talano JV. Antimyocardial antibodies in patients with coronary heart disease. Am Heart $\mathcal{F}$ 1972;83:612-9.

29 Liem KL, Ten Veen JH, Lie KI, Feltcamp TEW, Durrer D. Incidence and significance of heart muscle antibodies in patients with acute myocardial infarction and unstable angina. Acta Med Scand 1979;206:473-5.

30 Goodkind MJ, Bloomer WE, Goodver AUN. Recurrent pericardial effusion after nonpenetrating chest trauma: report of two cases treated with adrenocortical steroids. N Engl f Med 1960;263:874-81.

31 Segal F, Tabatznik B. Postpericardiotomy syndrome following penetrating stab wounds in the chest: comparison with the postcommissurotomy stab wounds in the chest: comparis

32 Tabatznik B, Isaacs JP Postpericardiotomy syndrome following traumatic hemopericardium. Am f Cardiol 1961;7:83-96.

33 Dressler $W$. Postcardiotomy syndrome after implantation of a pacemaker. Am Hearl f 1962;63:757-9.

34 Treasure $\mathrm{T}$. Hearts and minds: how big is the risk of coronary surgery? $\mathrm{Br} \mathrm{F}$ Hosp Med 1987;37:9.

Accepted 19 February 1988
Department of Obstetrics and Gynaecology, Helsinki University Central Hospital, and the Children's Hospital, University of Helsinki, Finland Vineta J Ruth, MD, research fellow

Kari O Raivio, MD, professor of perinatology

Correspondence and requests for reprints to: Dr V J Ruth, Children's Hospital, 00290 Helsinki, Finland.

\title{
Perinatal brain damage: predictive value of metabolic acidosis and the Apgar score
}

\author{
Vineta J Ruth, Kari O Raivio
}

\begin{abstract}
To assess the predictive value for perinatal brain damage of acidosis at birth, alone or in combination with the Apgar score at 5 minutes, a cohort of 982 liveborn infants delivered over two months was studied prospectively. The umbilical cord was double clamped, and arterial acid-base values were successfully determined in 964 infants and lactate concentration in 931. Reference values defining acidosis (mean \pm 2 SD) were obtained from a subset of 127 term infants who had no complications. The incidence of a low $\mathrm{pH}$ was $12 \%$ (111 out of 964 ), high base deficit $7 \%$ ( 70 out of 964 ), high lactate concentration 9\% (83 out of 931), and low Apgar score at 5 minutes $(\leqslant 7) 3 \%$ (32 out of 982 ). Twelve of the 111 infants (11\%) with acidosis had a low Apgar score, and 12 out of 29 infants (41\%) with low Apgar scores had acidosis. At one year of age 35 infants were lost to follow up and 22 had an adverse outcome unrelated to asphyxia; 883 infants showed normal development but the possible sequelae of asphyxia were four deaths, slight abnormalities in 28 infants, and clear abnormalities in 10 . The sensitivity and the positive predictive value of low $\mathrm{pH}$ for adverse outcome were, respectively, 21 and $8 \%$, of high lactate concentration 12 and 5\%, and of low 5 minute Apgar score 12 and $19 \%$.
\end{abstract}

Metabolic acidosis determined in blood from the umbilical artery at birth is a poor predictor of perinatal brain damage.

\section{Introduction}

Perinatal asphyxia is an important cause of mortality and morbidity in the newborn infant and of neuro- logical disability, mainly cerebral palsy, in later life. This view is widely accepted, although asphyxia as a pathophysiological and clinical concept is quite loosely defined. Its components are hypoxia, hypercapnia, and ischaemia, but both its incidence and role in outcome are difficult to evaluate because of lack of reliable diagnostic criteria.

The Apgar score at 5 minutes after birth has been used, and often misused, as a predictor of neurological damage due to asphyxia. The American collaborative perinatal project of 1959-66, however, showed poor sensitivity of the Apgar score in this respect: only $27 \%$ of children who later developed cerebral palsy scored below 7 at 5 minutes. ${ }^{\prime}$ Metabolic acidosis reflects fetal distress and asphyxia, but its relation to the Apgar score is not close. In a cohort study in Oxford in 1982 only $19 \%$ of the infants with low Apgar scores had severe acidosis at birth and $27 \%$ of the infants with acidosis had a low score at 5 minutes. ${ }^{2}$ Determining the $\mathrm{pH}$ of blood in the umbilical artery has become an important measure of the infant's condition at birth and is used routinely in many delivery hospitals. The importance of acidosis at birth has not, however, been related to long term outcome in a sufficiently large unselected population that has received adequate follow up. We assessed the predictive value of acidosis at birth and the 5 minute Apgar score for perinatal brain damage in a defined delivery cohort.

\section{Subjects and methods}

The study was approved by the ethical committees of both hospitals. It was based on the deliveries over two months (April-May 1984) in the department of obstetrics and gynaecology, a unit admitting 
both normal parturients and those referred because they were at high risk. All liveborn infants were included. Fetal heart rate was electronically monitored in all deliveries. All infants had an Apgar score assigned according to clinical routine by a midwife or paediatrician at 1 and 5 minutes of age.

The umbilical cord was double clamped before the first breath, and the segment of cord was immediately placed on ice. Umbilical arterial blood was drawn into a heparinised syringe and the blood gases analysed within a median time of eight minutes with a Corning 178 automatic blood gas analyser. Two aliquots of arterial blood were precipitated with perchloric acid and stored at $-18^{\circ} \mathrm{C}$ until lactate concentration was determined by an enzymatic method (Boehringer Mannheim, kit No 149993). The procedures were performed by specialist research workers to ensure proper clamping and sampling. A form with relevant maternal, obstetric, and neonatal data was completed after the delivery and checked before the baby was discharged.

Follow up-As all infants in Finland are examined at the age of 1 year in well baby clinics by a general practitioner or paediatrician using a standardised protocol a questionnaire was sent to the clinics of the surviving infants to obtain information on development and an overall evaluation of the child. This inquiry was approved by the Ministry of Social Affairs and Health and the local health boards and presupposed parental consent. The infants were preliminarily classified into three groups: (a) normal, $(b)$ questionable, and (c) abnormal. All infants in the questionable and abnormal groups were re-evaluated and reclassified by a paediatrician or neurologist, or both. Infants were considered to be clearly abnormal if they had cerebral palsy or showed a noticeable delay in developmentfor example, an inability to sit and stand at the age of 12 months. All clear abnormalities were confirmed in a thorough neurological examination. Infants were

TABLE I-Characteristics of infants studied $(n=982)$

\begin{tabular}{lr}
\hline Characteristic & Noof subjects \\
\hline Maternal complication: & \\
Pre-eclampsia & 69 \\
Diabetes mellitus & 32 \\
Obstetric hepatosis & 28 \\
Twin pregnancy & 13 \\
Mode of delivery: & \\
Caesarean section & 128 \\
Elective & 54 \\
Emergency & 800 \\
Vaginal delivery & 33 \\
Gestational age (weeks): & 863 \\
$>41$ & 86 \\
$37-41$ & 76 \\
<37 & 50 \\
Birth weight: & 18 \\
<2500g & \\
Small for gestational age & 19 \\
Large for gestational age & 27 \\
Apgar score at l minute: & 936 \\
$0-3$ & 37 \\
4-6 & 26 \\
$7-10$ & 10 \\
Intubated at birth & 12 \\
Mechanical ventilation & 5 \\
Respiratory distress syndrome & 11 \\
Meconium aspiration syndrome & 10 \\
Hypoxic-ischaemic encephalopathy & \\
Major congenital anomaly & \\
Died & \\
\hline
\end{tabular}

TABLE II-Mean $(S D) p H$, base deficit, and lactate values in umbilical arterial blood of infants delivered vaginally and by elective caesarean section

\begin{tabular}{|c|c|c|c|c|}
\hline & $\begin{array}{l}\text { Vaginal delivery } \\
\qquad(\mathrm{n}=106)\end{array}$ & $\begin{array}{l}95 \% \text { Confidence } \\
\text { interval }\end{array}$ & $\begin{array}{l}\text { Elective section } \\
\qquad(n=21)\end{array}$ & $\begin{array}{l}95 \% \text { Confidence } \\
\text { interval }\end{array}$ \\
\hline $\mathrm{pH}$ & $7.29(0.07)$ & $7 \cdot 28$ to $7 \cdot 31$ & $7 \cdot 31(0.03)$ & $7 \cdot 29$ to $7 \cdot 32$ \\
\hline Base deficit $(\mathrm{mmol} / \mathrm{l})$ & $4 \cdot 7(4 \cdot 0)$ & 3.9 to 5.5 & $2 \cdot 5(2 \cdot 2)$ & 1.5 to 3.5 \\
\hline Lactate $(\mathrm{mmol} / \mathrm{l})$ & $2 \cdot 9(1 \cdot 2)$ & $2 \cdot 7$ to $3 \cdot 2$ & $2.0(0.6)$ & $1 \cdot 7$ to $2 \cdot 3$ \\
\hline
\end{tabular}

classified as slightly abnormal if they showed transient abnormalities in muscle tone or an abnormal pattern of development in motor functions during the first year or if a slight delay in development was noted at the age of 12 months-for example, an inability to stand up. Infants with an adverse outcome were excluded when the damage could clearly be ascribed to a disease unrelated to asphyxia.

Analysis of data-To estimate the prognostic value of the variables studied the sensitivity (percentage of abnormal test results among damaged infants), specificity (percentage of normal test results among normally developing infants), positive predictive value (percentage of damaged infants among those with abnormal test results), and negative predictive value (percentage of normally developing infants among those with normal test results) were calculated. The data were analysed with the biomedical progams (BMDP) statistical package. Analysis of variance and the $\chi^{2}$ test were used in comparing the neonatal data of the infants lost to follow up with the data of those examined. Linear regression or Welch's $t$ test was used in analysing the effect of several maternal and obstetric variables on umbilical arterial $\mathrm{pH}$. The variables with significant effects were further analysed by the MantelHaenszel test to evaluate possible influences on the prognostic value of $\mathrm{pH}$.

\section{Results}

During the study a total of 982 infants were born alive. Table I shows their main clinical characteristics. The function of this hospital as a referral centre is reflected in the number of mothers with diabetes and complications of pregnancy as well as the high incidence of low birth weight $(8 \%)$ and caesarean section $(19 \%)$.

For defining reference values of the variables studied a subgroup of healthy infants was chosen according to the following criteria: $(a)$ no maternal chronic disease, (b) no complication of pregnancy or delivery, $(c)$ no neonatal disturbance, and $(d)$ normal infant development. These criteria were met by 127 infants in the cohort. The Apgar score was not used as a criterion of selection, but all 127 infants scored 9-10 at 5 minutes of age. As the mode of delivery influences acid-base values in the blood of the umbilical artery ${ }^{3}$ separate reference values were calculated for the 106 infants delivered vaginally and the 21 infants delivered by elective caesarean section (table II). We defined the reference range as the mean \pm 2 SD. With this the lower limit of normal umbilical arterial $\mathrm{pH}$ was $7 \cdot 16$ after vaginal delivery and $7 \cdot 25$ after elective caesarean section, whereas the corresponding upper limits for lactate concentration were 5.4 and $3.3 \mathrm{mmol} / \mathrm{l}$ and for base deficit 12.7 and $6.8 \mathrm{mmol} / \mathrm{l}$. As the values for base deficit were not normally distributed $5 \%$ of the reference group values exceeded the 2 SD limit.

Lactate concentration was successfully determined in 931 infants, and $83(9 \%)$ had a raised value. Acidbase values were successfully determined in 964 infants, of whom $111(12 \%)$ had a low $\mathrm{pH}$ and $70(7 \%)$ an increased base deficit. The Apgar score at 5 minutes was 7 or lower in 32 out of 982 infants (3\%). Only 12 of the 111 infants $(11 \%)$ with acidosis had a low Apgar score, and 12 out of 29 infants (41\%) with low Apgar scores had acidosis at birth (table III). Six infants had a $\mathrm{pH}$ below 7.00, and three of them had low scores $(5$ minute Apgar score 5-7). Three infants had an Apgar score of 0-3 at 5 minutes, of whom one had acidosis (pH 7·11).

The effect of several maternal and obstetric risk factors on umbilical arterial $\mathrm{pH}$ was evaluated. Significantly lower $(\mathrm{p}<0.001) \mathrm{pH}$ values were measured with infusion of oxytocin, epidural anaesthesia for vaginal delivery, long duration of labour (over 12 hours) and 
TABLE III-Relation between Apgar score at 5 minutes and umbilical arterial $p H$. Values are numbers of infants

\begin{tabular}{lccc}
\hline & \multicolumn{2}{c}{ Apgar score at 5 minutes } & \\
\cline { 2 - 3 } Umbilical arterial $\mathrm{pH}$ & $\leqslant 7$ & $>7$ & Total \\
\hline Low & 12 & 99 & 111 \\
Normal & 17 & 836 & 853 \\
\hline Total & 29 & 935 & 964 \\
\hline
\end{tabular}

* See text for definition

delivery (over 30 minutes), meconium staining of amniotic fluid, and cord compression. These differences were, however, considered to be clinically unimportant as the average $\mathrm{pH}$ was decreased by only $0.02-0.04$ units. No effect of maternal diabetes, preeclampsia, obstetric hepatosis, or intrauterine growth retardation was observed on umbilical arterial $\mathrm{pH}$. In comparison with the whole group preterm delivery (gestational age below 37 weeks) was associated with a higher incidence of a low Apgar score (12\% (10 out of 86 infants)) but not of acidosis ( $11 \%$ ( 9 out 86$)$ ). All five infants with hypoxic-ischaemic encephalopathy had both a low Apgar score and acidosis at birth.

\section{DEVELOPMENTAL OUTCOME}

At 1 year of age 35 infants could not be traced because the family had moved, so the rate of response to the follow up was $96 \%$. The umbilical arterial $\mathrm{pH}$, base deficit, and lactate values and Apgar scores of the 35 infants lost to follow up did not differ from those of the reference group, and none of them had any important perinatal problems. Twenty two infants had an adverse outcome caused by a specific cause unrelated to asphyxia. Two died of a congenital malformation, two of an inborn error of metabolism, and one each of rhesus immunisation and septicaemia; abnormal development or neurological symptoms were ascribed to a congenital malformation in six infants, to genetic disease in two, to the fetal alcohol syndrome in three, to social deprivation in four, and to hypocalcaemia in one.

Of the remaining 925 infants, $883(95 \%)$ showed normal development, 28 slightly abnormal development, and 10 clearly abnormal development, and four asphyxiated infants born preterm had died. Thus altogether 42 infants had an adverse outcome with perinatal asphyxia as a possible or the most credible cause. Table IV shows the clinical details of the four infants who died and the 10 who showed clearly abnormal development; four of the 10 had cerebral palsy. Eleven infants with transient motor impairment and 17 with a slight delay in development constituted the 28 infants with slightly abnormal development at 1 year of age. None of those with transient motor impairment but six of those with slightly abnormal development were born prematurely.

Table V shows the sensitivity, specificity, and positive and negative predictive values of the variables studied with respect to adverse outcome. The positive

TABLE V-Prediction of adverse outcome. Values are percentages (proportions)

\begin{tabular}{|c|c|c|c|c|}
\hline & $\begin{array}{l}\text { Umbilical } \\
\text { arterial pH }\end{array}$ & $\begin{array}{c}\text { Lactate } \\
\text { concentration }\end{array}$ & $\begin{array}{c}\text { Apgar } \\
\text { score at } \\
5 \text { minutes }\end{array}$ & $\begin{array}{c}\text { Apgar } \\
\text { score } \\
\text { and pH }\end{array}$ \\
\hline Sensitivity & $21(9 / 42)$ & $12(4 / 34)$ & $12(5 / 42)$ & $7(3 / 42)$ \\
\hline $\begin{array}{l}\text { Specificity } \\
\text { Predictive va }\end{array}$ & $89(767 / 866)$ & $91(768 / 843)$ & $98(861 / 883)$ & ) $99(858 / 866)$ \\
\hline \multicolumn{5}{|c|}{ Predictive value: } \\
\hline Positive & $8(9 / 108)$ & $5(4 / 79)$ & $19(5 / 27)$ & $27(3 / 11)$ \\
\hline Negative & $96(767 / 800)$ & $96(768 / 798)$ & $96(861 / 898)$ & $96(858 / 897)$ \\
\hline
\end{tabular}

predictive value of a low $\mathrm{pH}(8 \%)$ did not improve in combination with the lactate value, and lactate concentration alone had a low predictive value. When low $\mathrm{pH}$ and low Apgar score were combined the positive predictive value increased to $27 \%$, but this combination, although specific, was insensitive. The number of infants with severe acidosis ( $\mathrm{pH}$ below 7.00), with or without a low Apgar score, was too few for statistical evaluation, but only one of six such infants was slightly abnormal at follow up. Death, cerebral palsy (table IV), and transient motor impairment were not predicted any better than overall adverse outcome.

The poor predictive value of metabolic acidosis could be due to a confounding factor that would decrease the $\mathrm{pH}$ without having an influence on outcome. To rule out such a possibility the relation between $\mathrm{pH}$ and outcome was tested separately for infants with and without the risk factors, mentioned above, that had a significant effect on umbilical arterial $\mathrm{pH}$. None of these risk factors had an influence on the prognostic value of $\mathrm{pH}$.

\section{Discussion}

The incidence of low umbilical arterial $\mathrm{pH}$ was about $6 \%$ in previous cohort studies, when the mean -1 SD $(7 \cdot 11)$ of the study group ${ }^{2}$ or an arbitrary value of $7 \cdot 15^{4}$ was taken as the lower limit of normal $\mathrm{pH}$. The limit in other studies has varied from $7 \cdot 09$ to $7 \cdot 25,{ }^{5.7}$ depending on the definition of normality. The most commonly

TABLE IV-Clinical data on infants who died or who were clearly abnormal at 1 year of age

\begin{tabular}{|c|c|c|c|c|c|c|c|}
\hline \multirow{2}{*}{$\begin{array}{l}\text { Case } \\
\text { No }\end{array}$} & \multirow{2}{*}{$\begin{array}{l}\text { Gestational } \\
\text { age (weeks) }\end{array}$} & \multirow{2}{*}{$\begin{array}{l}\text { Birth weight } \\
(\mathrm{g})\end{array}$} & \multirow{2}{*}{$\begin{array}{l}\text { Umbilical } \\
\text { arterial pH }\end{array}$} & \multicolumn{2}{|c|}{ Apgar score } & \multirow[b]{2}{*}{ Neonatal diagnosis } & \multirow[b]{2}{*}{ Outcome } \\
\hline & & & & At 1 minute & At 5 minutes & & \\
\hline 1 & 22 & 630 & $7 \cdot 11$ & 0 & 0 & Asphyxia & Died aged 20 minutes \\
\hline 2 & $26 \cdot 3$ & 920 & $7 \cdot 24$ & 3 & 8 & Respiratory distress syndrome & Died aged 12 hours \\
\hline 3 & $27 \cdot 7$ & 940 & $7 \cdot 40$ & 4 & 6 & $\begin{array}{l}\text { Respiratory distress syndrome, } \\
\text { intraventricular } \\
\text { haemorrhage }\end{array}$ & Died aged 3 days \\
\hline $4^{\star}$ & $28 \cdot 6$ & 615 & $7 \cdot 19$ & 1 & 6 & $\begin{array}{l}\text { Respiratory distress syndrome, } \\
\text { patency of ductus arteriosus, } \\
\text { bronchopulmonary } \\
\text { dysplasia }\end{array}$ & Died aged 2 weeks \\
\hline 5 & $26 \cdot 1$ & 670 & $7 \cdot 18$ & 4 & 6 & $\begin{array}{l}\text { Respiratory distress syndrome, } \\
\text { intraventricular } \\
\text { haemorrhage, apnoeic spells }\end{array}$ & Hemiplegia \\
\hline 6 & $36 \cdot 9$ & 3080 & $7 \cdot 23$ & 9 & 9 & Second born twin & Developmental delay \\
\hline $7 \star$ & $38 \cdot 9$ & 3930 & $7 \cdot 19$ & 9 & 9 & None & Developmental delay \\
\hline 8 & $39 \cdot 6$ & 4720 & $7 \cdot 15$ & 8 & 9 & None & Developmental delay \\
\hline 9 & $39 \cdot 7$ & 2920 & $7 \cdot 28$ & 10 & 10 & Hyperbilirubinaemia & Hemiplegia \\
\hline 10 & $40 \cdot 1$ & 4920 & $7 \cdot 24$ & 9 & 9 & None & Developmental delay \\
\hline 11 & $40 \cdot 7$ & 3420 & $7 \cdot 15$ & 0 & 3 & $\begin{array}{l}\text { Hypoxic-ischaemic } \\
\text { encephalopathy, seizures }\end{array}$ & Tetraplegia \\
\hline 12 & $41 \cdot 1$ & 3500 & $7 \cdot 37$ & 9 & 10 & None & Developmental delay \\
\hline 13 & $41 \cdot 4$ & 3940 & $7 \cdot 28$ & 8 & 9 & Facial nerve palsy & Hemiplegia \\
\hline 14 & $42 \cdot 3$ & 4500 & $7 \cdot 16$ & 9 & 9 & None & Developmental delay \\
\hline
\end{tabular}

${ }^{\star}$ Delivered by elective caesarean section. 
used cut off points have been derived from the total population studied and thus may be influenced by the type of hospital. We based our assessment on a reference group without any complications, separately for deliveries with and without labour. The only study defining normal values for umbilical arterial $\mathrm{pH}$ in a sizable group of uncomplicated vaginal deliveries at term reported a cut off point (mean $-2 \mathrm{SD}=7 \cdot 18$ ) close to ours. ${ }^{8}$ The incidence of acidosis at birth in our study group (11\%) thus gives a formally correct estimate of this abnormality but, of course, reflects the nature of the patients studied.

\section{PREDICTING BRAIN DAMAGE}

Predicting the risk of brain damage during the neonatal period would be desirable for several reasons. It may be important in certain decisions about treatment in neonatal intensive care. It would help in identifying those infants who would benefit from more frequent and detailed follow up than usual to detect as early as possible those developmental abnormalities that are amenable to early rehabilitation. These include the cerebral palsies as well as visual and hearing problems. For such purposes a predictive test should have high sensitivity, so that infants needing special supervision would not be left out, and a reasonable positive predictive value, so that among the follow up group the number of infants subsequently developing normally would not be excessive compared with those found to require special care.

The poor correlation of the Apgar score, even when recorded at 5 minutes, with neurological outcome has previously been noted. The low positive predictive value, $19 \%$ in our study, means that about $80 \%$ of a group at risk as defined by a low Apgar score will be normal on follow up. In practice this is not an unreasonable ratio of normal to abnormal. The real problem is the low sensitivity-that is, only $12 \%$ of those with an eventual adverse outcome would be subjected to special follow up if the Apgar score at 5 minutes were the only criterion. This is even less than the $27 \%$ found in a previous study.'

For this reason we evaluated the applicability of metabolic acidosis at birth in defining a group at risk of brain damage. Blood from the umbilical cord, either venous or preferably arterial, can easily be obtained routinely at any delivery. As umbilical arterial $\mathrm{pH}$ may reflect not only fetal hypoxia and anaerobic metabolism but also maternal respiratory state, although only to a small extent," we considered base deficit and lactate concentration as possible predictive variables in comparison with $\mathrm{pH}$, alone or in combination with the Apgar score. Unfortunately, we failed to find a variable better or even as good as the Apgar score in predicting adverse outcome. The somewhat higher sensitivity of umbilical arterial $\mathrm{pH}(21 \%)$ was offset by its lower specificity and positive predictive value. The other indices of metabolic acidosis were no better.

Previous studies on the outcome of a birth cohort in relation to metabolic acidosis have not been reported. Umbilical arterial pH in relation to outcome was studied in 121 infants with acidosis with incomplete follow up and without controls. ${ }^{4}$ Low $\mathrm{pH}$ in clinically normal newborn infants was not associated with a higher risk of later neurological sequelae. In preterm infants fetal acidosis was found to be more common in damaged than in normal survivors. ${ }^{10}$ Fetal hypoxia with more prolonged metabolic acidosis (defined on the basis of arterial buffer-base values) was interpreted to carry a higher risk of deficits in comparison with acidosis of shorter duration, "but the data were few and the differences not significant. In another study on term infants metabolic acidosis at birth was not associated with more neurological or developmental problems on follow up than normal acid-base values. ${ }^{12}$

Like the Apgar score, umbilical arterial $\mathrm{pH}$ is useful for clinical assessment of the newborn infant. It is also valuable to obstetricians, particularly in infants with suspected fetal hypoxia. Why is metabolic acidosis at birth such a poor predictor of perinatal brain damage? One explanation might be that the abnormal outcomes observed in our study were not related to perinatal asphyxia, even though other known causal factors were excluded. In addition, the hypoxic insult responsible for the damage may have occurred well before birth, ${ }^{13}$ and the associated metabolic abnormalities may have been compensated for by the time of birth. In the infants with acidosis the hypoxic episode may have been short. Equally probable, however, is that metabolic acidosis simply reflects physiological adaptation to the stress of delivery and asphyxia. Redistribution of blood flow to vital organs and the switch to anaerobic metabolism are usually successful in averting permanent damage, and survivors of extremely severe asphyxia often show a full neurological recovery. ${ }^{14}$ Therefore perhaps signs of cell or tissue damage should be sought as more reliable prognostic indicators. These may include the leakage of specific enzymes-for example, creatine kinase $\mathrm{BB}$, which is specific to the brain - or other neuronal proteins, ultrasonic evidence of cerebral ischaemia, ${ }^{15}$ or signs of irreversible energy failure detected by nuclear magnetic resonance spectroscopy..$^{16}$

We thank Dr Maija Pohjavuori, Dr Kim Vettenranta, and the medical students Eija Haapanen, Kaija-Leena Kolho, Taina Lindgren, Leena Mäntylä, and Anna-Mari Outinen for participating in cord blood sampling. The study was supported by the Sigrid Juselius Foundation, the Signe and Ane Gyllenberg Foundation, the Foundation for Pediatric Research, and Finska Läkaresällskapet.

I Nelson $\mathrm{KB}$, Ellenberg JH. Apgar scores as predictors of chronic neurologic disability. Pediatrics 1981;68:36-44.

2 Sykes GS, Molloy PM, Johnson P, et al. Do Apgar scores indicate asphyxia? Lancet 1982;i:494-6.

3 Modanlou H, Yeh S-Y, Hon EH, Forsythe A. Fetal and neonatal biochemistry and Apgar score. Am $\mathcal{F}$ Obstet Gynecol 1973;117:942-51

4 Lauener PA, Calame A, Janacek P, Bossart H, Monod JF. Systematic pH measurements in the umbilical artery: cause and predictive value of neonatal acidosis. F Perinat Med 1983;11:278-85.

5 Huisjes HJ, Aarnoudse JG. Arterial or venous umbilical pH as a measure of neonatal morbidity? Early Hum Dev 1979;3:155-61.

6 Litschgi M, Beuz JJ, Glatthaar E. Aktuelle und prognostische Bedeutung des arteriellen Nabelschnur-pH für die postpartale Zustandsdiagnostik. Z Geburtshilfe Perinatol 1974;178:23-9.

7 Goldenberg RL, Huddleston JF, Nelson KG. Apgar scores and umbilical arterial $\mathrm{pH}$ in preterm newborn infants. Am $\mathcal{F}$ Obstet Gynecol 1984;149: $651-4$.

8 Yeomans ER, Hauth JC, Gilstrap LC, Strickland DM. Umbilical cord pH, $\mathrm{PCO}_{2}$, and bicarbonate following uncomplicated term deliveries. Am $\mathrm{f} \mathrm{Obstet}$ Gynecol 1985; 151:798-800.

9 Dijxhoorn MJ, Visser GH, Huisjes HJ, Fidler V, Touwen BC. The relation between umbilical $\mathrm{pH}$ values and neonatal neurological morbidity in full term appropriate-for-dates infants. Early Hum Dev 1985;11:33-42.

10 Westgren $M$, Holmquist P, Ingemarsson I, Svenningsen N. Intrapartum fetal acidosis in preterm infants: fetal monitoring and long-term morbidity. Obstet Gynecol 1984;63:355-9.

11 Low JA, Galbraith RS, Muir DW, Killen HL, Pater EA, Karchmar EJ. Factors associated with motor and cognitive deficits in children after intrapartum fetal hypoxia. Am J Obstet Gynecol 1984;148:533-9.

12 Low JA, Galbraith RS, Muir DW, Killen HL, Pater EA, Karchmar EJ. Intrapartum fetal hypoxia: a study of long-term morbidity. Am $\mathcal{F}$ Obstel Gynecol 1983;145:129-34.

13 Volpe JJ. Neurology of the newborn. 2nd ed. Philadelphia: WB Saunders Co, 1987:236-7.

14 Hill A, Volpe JJ. Hypoxic-ischemic brain injury in the newborn. Semin Perinatol 1982;6:25-41.

15 Graham M, Levene MI, Trounce JQ, Rutter N. Prediction of cerebral palsy in very low birthweight infants: prospective ultrasound study. Lancet 1987 ;ii: 593-6.

16 Hope PL, Costello AM de L, Cady EB, et al. Cerebral energy metabolism studied with phosphorous NMR spectroscopy in normal and birthasphyxiated infants. Lancet 1984;ii:366-70.

(Accepted 12 April 1988) 